\title{
Effects of Synchronization of Donor Cell Cycle on Embryonic Development and DNA Synthesis in Porcine Nuclear Transfer Embryos
}

\author{
Kei MIYAMOTO ${ }^{1)}$, Yoichiro HOSHINO ${ }^{2)}$, Naojiro MINAMI ${ }^{1}$, \\ Masayasu YAMADA ${ }^{1)}$ and Hiroshi IMAI') \\ 1) Laboratory of Reproductive Biology, Graduate School of Agriculture, Kyoto University, Kyoto \\ 606-8502 and ${ }^{2)}$ Hida Beef Cattle Research, Gifu Prefectural Livestock Research Institute, Gifu \\ 506-0101, Japan
}

\begin{abstract}
The relationship between donor cell cycle and the developmental ability of somatic cell nuclear transfer (SCNT) embryos has not fully been elucidated. Donor cells that are usually prepared by serum starvation or confluent-cell culture for SCNT represent a heterogeneous population that includes mainly G0 phase cells, other cells in different phases of the cell cycle and apoptotic cells. In this study, we compared the developmental ability of porcine SCNT embryos reconstructed from G0 phase cells (G0-SCNT embryos) and strictly synchronized-G1 phase cells (G1-SCNT embryos), and examined the developmental rates and timing of first DNA synthesis. The G0 phase cells were synchronized by confluent culture, and the G1 phase cells were prepared from actively dividing $\mathrm{M}$ phase cells. The G1-SCNT embryos showed a significantly higher $(\mathrm{P}<0.05)$ developmental rate to the blastocyst stage per cleaved embryo (59\%) than the G0-SCNT embryos (43\%). Moreover, initiation of first DNA synthesis and cleavage occurred significantly earlier in the G1-SCNT embryos than in the G0-SCNT embryos. Delay of initiation of first DNA synthesis in the SCNT embryos by aphidicolin resulted in decreased developmental rates to the blastocyst stage without any effect on cleavage rates. Our data demonstrates that synchronized-G1 phase cells can be used as donor cells for SCNT embryos and that earlier initiation of first DNA synthesis may be important for subsequent development of SCNT embryos. The SCNT system using G1-synchronized cells, in terms of their highly uniform and viable cell states, can be useful for studying the reprogramming processes and embryonic development of SCNT embryos.
\end{abstract}

Key words: Cell cycle synchronization, DNA synthesis, Nuclear transfer, Reprogramming

(J. Reprod. Dev. 53: 237-246, 2007)

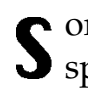
omatic cell-derived cloned animals from many species have been reported [1-9] since the first successful cloning from somatic cells was accomplished in sheep [1]. However, the efficiency of cloning is very low, and the appropriate conditions for reprogramming somatic cells are still unclear.

Accepted for publication: October 14, 2006

Published online: November 29, 2006

Correspondence: H. Imai (e-mail: imai@kais.kyoto-u.ac.jp)
The cell cycle of donor cells is a major factor that affects the efficiency of producing somatic cell nuclear transfer (SCNT) embryos [10]. Wilmut et al. [1] reported that G0 phase donor cells prepared by serum starvation can be used for SCNT and may facilitate nuclear reprogramming in unfertilized oocytes. Therefore, G0 cells synchronized by serum starvation or a confluent cell culture system have been widely used as donor cells for SCNT [11]. However, serum starvation causes reduced cell 
survival and increased DNA fragmentation [12] and apoptosis [13] in porcine cells. The confluent cell culture system is as effective for cell cycle synchronization as serum starvation, especially for arresting cells in the G0/G1 phase [14-16]. Moreover, SCNT embryos reconstructed with donor cells obtained by confluent cell culture or serum starvation do not show different developmental rates during in vitro development [17]. Donor cells prepared by serum starvation or confluent culture consist of a mixture of cell cycles $[12,14,16]$. It is unclear which cell cycle of donor cells is effective for nuclear reprogramming and production of cloned animals, and successful cloning has been achieved with cell types other than the G0 phase $[3,18,19]$. Because unfertilized oocytes quickly move to the G1 phase after activation and/or nuclear transfer, donor cells in the early G1 phase are considered to be synchronous with the cell cycle of recipient oocytes. In fact, high developmental ability has been reported for SCNT embryos using G1 cells as donor cells $[15,20]$. Although G1 phase cells have many common features with G0 phase cells, they are definitely distinct from G0 cells in that G1 cells are in a cell cycling state. Synchronized G1 phase cells are easily collected by treatment with a mitosis inhibitor, 2-methoxyestradiol, followed by the shake-off method [20], and they have been shown to effectively support development of SCNT embryos as donor cells to term [20]. Although both G0 and G1 cells can support high developmental ability for SCNT embryos in terms of developmental rates to term and/or the blastocyst stage, there is little information concerning the differences in nuclear reprogramming and early embryonic development between G0-SCNT and G1-SCNT embryos.

The onset of DNA synthesis in embryos is one of the most important steps in initiation of early preimplantation development. The duration of the first DNA replication positively correlates with high developmental rates to the blastocyst stage for in vitro-fertilized eggs in mice [21] and cattle [22]. Earlier onset of DNA synthesis in embryos correlates with a longer period of the first $\mathrm{S}$ phase [23]. The timing of DNA synthesis initiation depends on the donor cell cycle in bovine SCNT embryos [24]. However, there is little information about the relationship between first DNA synthesis and developmental rates in SCNT embryos.
In this study, we reconstructed SCNT embryos from synchronized donor cells at the G0 phase and G1 phase, and compared the timing of first DNA synthesis and developmental ability of SCNT embryos to the blastocyst stage to elucidate the critical steps of nuclear reprogramming for support of early embryonic development in pig SCNT embryos.

\section{Materials and Methods}

\section{In vitro maturation of oocytes}

Ovaries from domestic gilts (6 months old) were obtained at a local slaughterhouse. Follicles 3-6 $\mathrm{mm}$ in diameter were dissected with two scalpels as described by Hoshino et al. [25]. Briefly, 20-50 cumulus-oocyte complexes were collected and cultured in HEPES-buffered TCM-199 medium (Sigma-Aldrich, St. Louis, MO, USA) containing 2.2 $\mathrm{mg} / \mathrm{ml} \mathrm{NaHCO}$, $100 \mathrm{mg} / \mathrm{l}$ pyruvic acid (SigmaAldrich), $10 \%$ fetal bovine serum (FBS; JRH Bioscience, Inc., Kansas City, KS, USA), 50 mg/ml penicillin G (Sigma-Aldrich) and $50 \mathrm{mg} / \mathrm{ml}$ streptomycin (Meiji, Tokyo, Japan) (Medium A). They were then cultured with two inverted follicle shells in maturation medium, which consisted of TCM-199 medium (Sigma-Aldrich) containing 2.2 $\mathrm{mg} / \mathrm{ml} \mathrm{NaHCO} 3,100 \mathrm{mg} / 1$ pyruvic acid, $0.1 \mathrm{IU} / \mathrm{ml}$ human menopausal gonadotropin (Teikoku Zoki, Co., Tokyo, Japan), 10\% FBS, $50 \mathrm{mg} / \mathrm{ml}$ penicillin G and $50 \mathrm{mg} / \mathrm{ml}$ streptomycin, at $38.5 \mathrm{C}$ under humidified air containing $5 \% \mathrm{CO}_{2}$ for $44-45 \mathrm{~h}$.

\section{Cell cycle synchronization of donor cells}

Donor fibroblast cells were collected from the kidney of a male miniature Potbelly pig (10 months old). Small pieces of tissue from the kidney were placed in $3.5 \mathrm{~cm}$ culture dishes and cultured in Dulbecco's Modified Eagle's Medium (DMEM; Invitrogen, Carlsbad, CA, USA) containing 10\% FBS, $50 \mathrm{mg} / \mathrm{ml}$ penicillin $\mathrm{G}$ and $50 \mathrm{mg} / \mathrm{ml}$ streptomycin (Medium B) at $37 \mathrm{C}$ in $5 \% \mathrm{CO}_{2}$ in air. After removal of the explants, growing fibroblast cells were further cultured in Medium B. These porcine fibroblast cells were used at passages 2 to 10. The cells were synchronized at the G0 phase of the cell cycle by an additional 3 days of culture after reaching confluency in Medium B (confluent culture). Synchronized cells at the G1 phase were prepared as described by Urakawa et al. [20] with a 


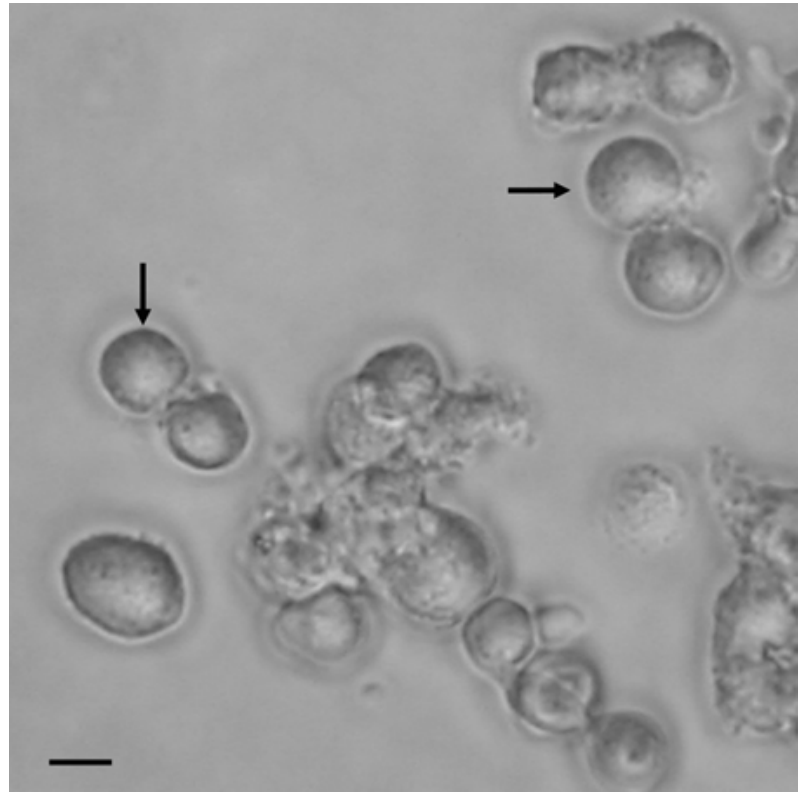

Fig. 1. Synchronized cells at the G1 phase. Cells just after dividing equally (arrows) were used as donor cells. Scale bar is $10 \mu \mathrm{m}$.

minor modification. Briefly, the growing cell culture in Medium B was changed to the Minimum Essential Medium without calcium ion (Invitrogen) supplemented with 10\% FBS, $2 \mathrm{mM}$ glutamine (Wako, Osaka, Japan) and 2-methoxyestradiol (Sigma-Aldrich), a mitotic inhibitor, at $1 \mu \mathrm{M}$ to synchronize cells to the $\mathrm{M}$ phase. After $30 \mathrm{~min}$ of culture at $37 \mathrm{C}$ in $5 \% \mathrm{CO}_{2}$ in air, the culture dish was shaken for $1 \mathrm{~min}$ to detach the $\mathrm{M}$ phase cells, and the supernatant was discarded. This treatment was repeated once, and finally the supernatant was collected and centrifuged at $200 \times \mathrm{g}$ for $5 \mathrm{~min}$. The $\mathrm{M}$ phase cells were resuspended in Medium A and cultured for $25 \mathrm{~min}$. Cells that had just cleaved equally were used for SCNT as G1-synchronized cells (Fig. 1).

\section{Somatic cell nuclear transfer (SCNT)}

In vitro-matured pig oocytes were used as recipient oocytes for SCNT. After $44-45 \mathrm{~h}$ of maturation culture, the oocytes were treated with 1 $\mathrm{mg} / \mathrm{ml}$ hyaluronidase (Sigma-Aldrich) to remove the surrounding granulosa and cumulus cells. Oocytes that clearly extruded a first polar body were selected as recipient cytoplasts. The first polar body and adjacent cytoplasm, presumably including the metaphase chromosomes, were extruded by squeezing with a glass needle and were stained with Hoechst 33342 (Sigma-Aldrich). Successful enucleation was confirmed by the appearance of a metaphase plate in the removed karyoplast when illuminated by ultraviolet light. Donor cells that were synchronized at the G0 or G1 phase were injected into the perivitelline space of enucleated oocytes. These couplets were settled between two needle electrodes (444-100; Meiwa Shoji, Osaka, Japan) attached to a micromanipulator (Narishige, Tokyo, Japan) and were fused by two direct current pulses of $30 \mathrm{~V}$ for 30 $\mu$ sec using an ECM 2001M (BTX, San Diego, CA, USA) in $0.3 \mathrm{M}$ mannitol solution containing 0.05 $\mathrm{mM} \mathrm{CaCl}_{2}$ and $0.1 \mathrm{mM} \mathrm{MgSO}_{4}$.

The reconstructed embryos were cultured in porcine zygote medium-3 (PZM-3; [26]) at 38.5 C in $5 \% \mathrm{CO}_{2}$ in air for $144 \mathrm{~h}$. The developmental rates of the reconstructed embryos to each embryonic stage were examined every $24 \mathrm{~h}$ until $144 \mathrm{~h}$ after activation, and cleavage rates were assessed at $48 \mathrm{~h}$ of culture. The developmental rates are the proportions of embryos that developed to each stage. To compare the developmental rates of SCNT embryos to parthenogenetically activated (PA) embryos, matured oocytes were electronically activated by the same procedure.

\section{Control of DNA synthesis in SCNT embryos}

To delay the initiation of DNA synthesis during the first cleavage of SCNT and PA embryos, we added $1 \mu \mathrm{g} / \mathrm{ml}$ aphidicolin (Sigma-Aldrich), a reversible inhibitor of DNA polymerase $\alpha, \sigma$ and $\varepsilon$ [27], to PZM-3. After activation, G0-SCNT embryos, G1-SCNT embryos and PA embryos were randomly divided into two groups. The duration of aphidicolin treatment required to delay initiation of DNA synthesis was determined in a preliminary experiment. At $7 \mathrm{~h}$ after activation, only few embryos entered the $S$ phase; however, all embryos entered the $S$ phase at $14 \mathrm{~h}$ after activation (data not shown). Therefore, one group of embryos was treated with aphidicolin 7-14 $\mathrm{h}$ after activation, and the other group served as a control (no addition of aphidicolin).

\section{Detection of DNA synthesis of SCNT embryos}

DNA synthesis of SCNT and PA embryos was detected by incorporation of 5-bromo-2'deoxyuridine (BrdU) into embryonic DNA and immunofluorescene assay using a BrdU Labeling 
and Detection Kit I (1 296 7361; Roche Diagnostics, Indianapolis, IN, USA). Embryos were cultured in $100 \mu \mathrm{M}$ BrdU-containing medium 3-6, 6-9, 9-10.5 h or 10.5-12 $\mathrm{h}$ after fusion and activation of SCNT embryos or activation for PA embryos at $38.5 \mathrm{C}$ in $5 \% \mathrm{CO}_{2}$ in air. After culture, the zona pellucida was removed with $0.05 \%$ Actinase E (Kaken, Tokyo, Japan), and the embryos were fixed and treated with anti-BrdU and anti-mouse immunoglobulinfluorescein solution. Finally, the embryos were stained with propidium iodide (Sigma-Aldrich) to confirm whether a somatic cell nucleus successfully entered into the recipient cytoplasm. The BrdU signals of the embryos were examined using fluorescent microscopy, and the onset of DNA synthesis was compared among the G0-SCNT, G1SCNT and PA embryos.

\section{Differential staining of ICM and trophectoderm cells in blastocysts}

The number of cells at the blastocyst stage was counted at $150 \mathrm{~h}$. After removal of the zona pellucida, blastocysts were incubated in PBS with $10 \%$ rabbit anti-pig antiserum for $15 \mathrm{~min}$ at $37 \mathrm{C}$. Then, they were incubated in PBS with 5\% guinea pig complement (Sigma-Aldrich) for $15 \mathrm{~min}$ at $37 \mathrm{C}$. Subsequently, the embryos were washed in PBS (4 C) with $10 \mu \mathrm{g} / \mathrm{ml}$ propidium iodide and were fixed in ethanol containing $10 \mu \mathrm{g} / \mathrm{ml}$ Hoechst 33342 overnight at $-20 \mathrm{C}$. Trophectoderm cells were recognized by the red fluorescence of propidium iodide under a fluorescence microscope, and inner cell mass (ICM) cells were identified by blue fluorescence.

\section{Semiquantitative Reverse Transcription Polymerase Chain Reaction (RT-PCR) of SCNT embryos}

Purification of total RNA for RT-PCR was carried out on a single SCNT and PA embryo at the blastocyst stage using a ToTally RNA kit (Ambion, Austin, TX, USA). Briefly, the total RNAs were extracted with acid-phenol/chloroform, precipitated by ethanol with glycogen and treated with DNase for $20 \mathrm{~min}$ at room temperature. For reverse transcription, SuperScript III (Invitrogen) was added to the total RNA solution and incubated at $25 \mathrm{C}$ for $10 \mathrm{~min}, 50 \mathrm{C}$ for $55 \mathrm{~min}$ and at $70 \mathrm{C}$ for 15 min. PCR amplification was carried out on $1 \mu \mathrm{l}$ of RT product from an embryo per $20 \mu \mathrm{l}$ of PCR reaction mixture comprised of $13.3 \mu \mathrm{l}$ of water, $2 \mu \mathrm{l}$ of $10 \times$ PCR buffer (TaKaRa, Kyoto, Japan), $1.6 \mu$ of
$2.5 \mathrm{mM}$ dNTP (TaKaRa), $2 \mu \mathrm{l}$ of each sense and antisense primer and $0.1 \mu \mathrm{l}$ of ExTaq (TaKaRa). The PCR cycles for detection of Oct4 (Pou5f1) and $\beta$ actin $(A c t b)$ gene expression were conducted as follows: preheating reaction at $94 \mathrm{C}$ for $2 \mathrm{~min}$ for denaturation and 32 cycles of denaturation at $94 \mathrm{C}$ for $30 \mathrm{sec}$, annealing at $64 \mathrm{C}$ for $30 \mathrm{sec}$ and extension at $72 \mathrm{C}$ for $30 \mathrm{sec}$. The last cycles were followed by a 7 min extension reaction at $72 \mathrm{C}$. The PCR primers were designed for Oct4 (GenBank accession number, AJ251914; sense, 5'CGAGTGAGAGGCAACCTGGA-3'; antisense, 5' AGCCCAGAGGGGTGACAGAC-3' for a 346 base pairs [bp] product) and for $\beta$-actin (GenBank accession number, AJ312193; sense, 5' GCCCATCTACGAGGGGTACG-3'; antisense, 5' CACGTCGCACTTCATGATCG-3' for a 374 bp product). Ten $\mu$ l of the PCR products was visualized on $2 \%$ agarose gel under ultraviolet light. Relative band intensities were determined using a densitograph (model 4.0A; Atto, Tokyo, Japan) during the exponential stage of PCR amplification. The exponential stage was confirmed by three different PCR cycles. The intensities of Oct4 expression were presented relative to the intensity of the band for $\beta$-actin expression.

\section{Statistical analysis}

The developmental rates (Tables 1 and 4), cell numbers (Table 5), and expression levels of Oct4 gene at the blastocyst stage (Fig. 3B) were analyzed using analysis of variance (ANOVA). Differences in developmental progressions of SCNT embryos (Table 2) and initiation of DNA synthesis (Table 3) were analyzed by the Tukey method using the general linear model procedure of Statistical Analysis System (SAS Institute, Cary, NC, USA). Statistical significance was determined when the $\mathrm{P}$ value was less than 0.05 .

\section{Ethical approval}

All animal experiments were performed in accordance with the Institutional Animal Care and Use Committee of Kyoto University.

\section{Results}

\section{Developmental ability of SCNT embryos}

The developmental rates of the SCNT embryos 
Table 1. Developmental ability of SCNT embryos reconstructed from G0 or G1 cells

\begin{tabular}{lccccc}
\hline Groups & $\begin{array}{c}\text { No. of } \\
\text { trials }\end{array}$ & $\begin{array}{c}\text { No. of embryos } \\
\text { examined }\end{array}$ & $\begin{array}{c}\text { No. of embryos } \\
\text { cleaved (mean } \pm \text { SD } \%)\end{array}$ & $\begin{array}{c}\text { No. of embryos to } \\
\text { blastocysts (mean } \pm \text { SD } \%)\end{array}$ & $\begin{array}{c}\% \text { of blastocysts/cleaved } \\
\text { embryos (mean } \pm \text { SD } \%)\end{array}$ \\
\hline G0-SCNT & 6 & 89 & $62(69 \pm 7 \%)$ & $27(30 \pm 9 \%)$ & $43 \pm 12 \%$ \\
G1-SCNT & 6 & 103 & $63(63 \pm 10 \%)$ & $37(37 \pm 7 \%)$ & $59 \pm 3 \%^{\mathrm{a}}$ \\
\hline
\end{tabular}

a Values differ significantly within the same column $(\mathrm{P}<0.05)$.

reconstructed from G0 and G1 cells and cultured in PMZ-3 for $144 \mathrm{~h}$ are shown in Table 1 . There were no significant differences in cleavage rates and developmental rates to the blastocyst stage between the G0-SCNT and G1-SCNT embryos, but the developmental rate to the blastocyst stage per cleaved embryo was significantly higher in the G1SCNT embryos.

\section{Developmental progression of SCNT embryos}

The developmental stages of the embryos were examined every $24 \mathrm{~h}$ after nuclear transfer. The G1SCNT embryos developed faster at every developmental stage compared with the G0-SCNT embryos (Fig. 2). A distinct difference was observed from the first cleavage stage after $24 \mathrm{~h}$ (G0-SCNT, 44\%; G1-SCNT, 70\%). In contrast, most PA embryos (94\%) cleaved $24 \mathrm{~h}$ after culture. Additionally, compared with PA embryos, SCNT embryos exhibited a characteristic developmental pattern at the end of culture (Table 2); that is, a significantly higher population of G0-SCNT embryos were arrested at the 2-cell stage than G1SCNT embryos.

\section{Initiation of first DNA synthesis and the effect of delay of first DNA synthesis on embryonic development in SCNT embryos}

The timing of DNA synthesis of SCNT embryos was measured by the incorporation of BrdU 3-6, 69, 9-10.5 and 10.5-12 $\mathrm{h}$ after nuclear transfer (Table 3). Most PA embryos initiated DNA synthesis 6-9 $\mathrm{h}$ after nuclear transfer (83\%). In contrast, only a few SCNT embryos initiated DNA synthesis at $9 \mathrm{~h}$ after nuclear transfer, and most of them started synthesis 9-10.5 h after nuclear transfer. At 10.5-12 $h$ after nuclear transfer, embryos in all experimental groups began to synthesize DNA. Therefore, DNA synthesis of the PA embryos was initiated significantly earlier than that of the G1SCNT and G0-SCNT embryos. Moreover, initiation of DNA synthesis 9-10.5 h after nuclear transfer was significantly earlier in the G1-SCNT embryos
(86\%) than in the G0-SCNT embryos (63\%).

To confirm whether delay of first DNA synthesis affects the developmental rates, the timing of first DNA synthesis of SCNT and PA embryos was delayed by treatment with aphidicolin. As shown in Table 4, the developmental rate to blastocyst stage of the G0-SCNT embryos was significantly decreased compared to the non-treatment controls (3 and 31\%, respectively). However, aphidicolin treatment did not have any effect on the cleavage rates. A similar result was obtained in the G1SCNT embryos (aphidicolin treatment and control; 3 and $31 \%$, respectively) and PA embryos (23 and $64 \%$ ). Delay of first cleavage was observed in the aphidicolin-treated embryos. Most of the aphidicolin-treated G0-SCNT embryos did not cleave $24 \mathrm{~h}$ after activation (16\%), although $44 \%$ of the non-treated embryos cleaved. At $27 \mathrm{~h}$ after activation, 55\% of the aphidicolin-treated embryos cleaved, suggesting that the delay of first DNA synthesis was within $3 \mathrm{~h}$ in length. At $144 \mathrm{~h}$ after activation, $16 \%$ of the aphidicolin-treated and $4 \%$ of the non-treated embryos arrested at the morula stage.

\section{Cell number and Oct4 gene expression of SCNT embryos at the blastocyst stage}

The quality of SCNT embryos at the blastocyst stage was assessed by differential staining of ICM and trophectoderm cells and Oct4 gene expression. There were no significant differences in the total cell numbers of blastocysts or cell numbers of ICM and trophectoderm cells among the PA, G0-SCNT and G1-SCNT embryos (Table 5). Furthermore, there were no significant differences in the ratios of ICM cell numbers to total cell numbers of blastocysts among the different types of embryo (Table 5).

We conducted semiquantitative RT-PCR analysis of the SCNT and PA embryos. The relative amount of Oct4 transcripts in an individual blastocyst was calculated by the intensity of $\beta$-actin gene expression. Lower expression was observed for the 


\section{A G0-SCNT}

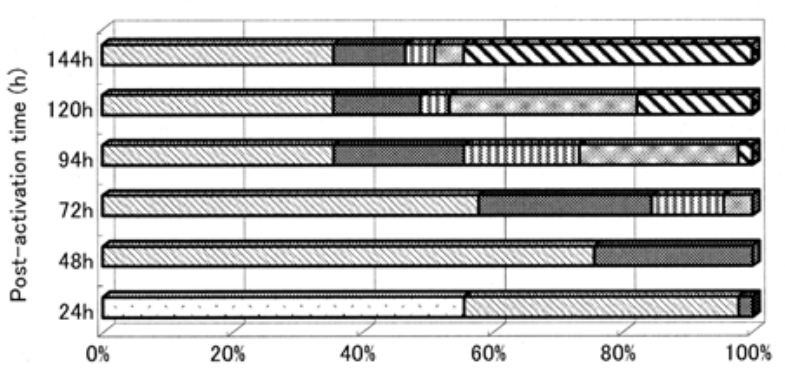

C PA

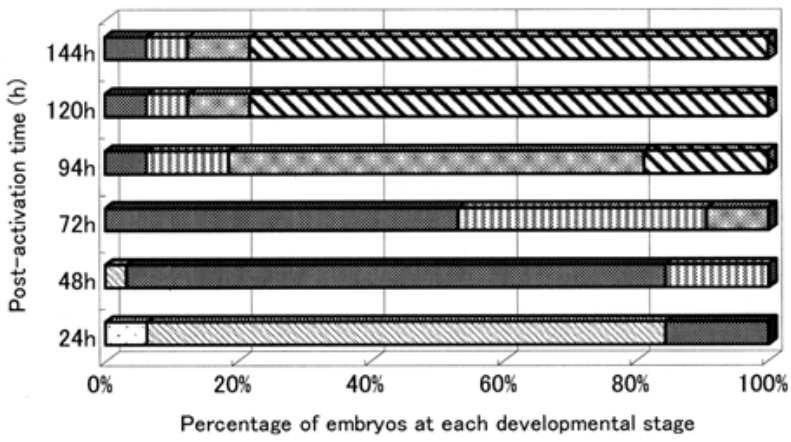

B G1-SCNT

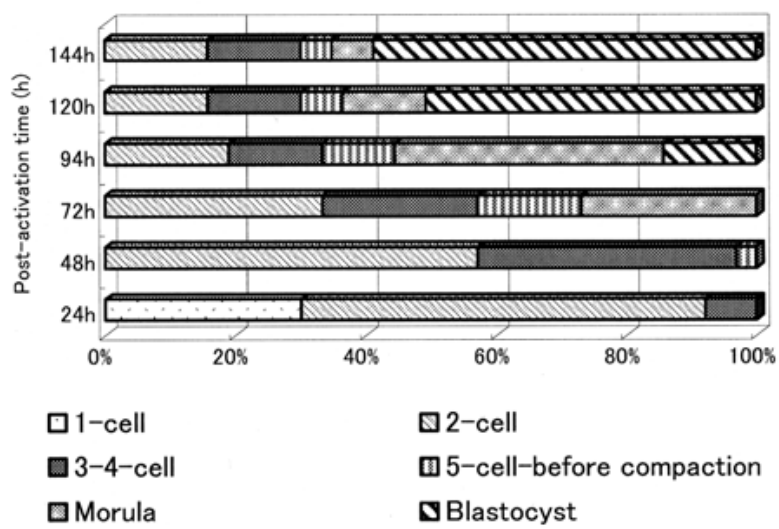

Fig. 2. Developmental progression of G0-SCNT, G1-SCNT and PA embryos. The developmental stages of embryos were examined every $24 \mathrm{~h}$. The proportion of embryos at each stage was represented as developed embryos per number of cleaved embryos from 48 to $144 \mathrm{~h}$ after activation, and the proportion of 1-, 2- and 3-cell stage embryos to total embryos (abnormally divided embryos were excluded) was examined after $24 \mathrm{~h}$. The data in Fig. 2 came from a portion of the data in Table 1 ( 5 trials in Table 1$)$.

Table 2. Differences in the developmental progression of G0-SCNT, G1-SCNT and PA embryos*

\begin{tabular}{cccc}
\hline Groups & $\begin{array}{c}\text { 2- and 3-cell } \\
\text { stages at 24 h }\end{array}$ & $\begin{array}{c}\text { 4- and 5-cell stages } \\
\text { at } 48 \mathrm{~h}\end{array}$ & $\begin{array}{c}\text { Embryos arrested at } \\
\text { the 2-cell stage }\end{array}$ \\
\hline G0-SCNT & $20 / 45(44 \%)^{\mathrm{c}}$ & $11 / 45(24 \%)^{\mathrm{f}}$ & $16 / 45(36 \%)^{\mathrm{g}}$ \\
G1-SCNT & $44 / 63(70 \%)^{\mathrm{b}}$ & $27 / 63(43 \%)^{\mathrm{e}}$ & $10 / 63(16 \%)^{\mathrm{h}}$ \\
PA $^{\#}$ & $30 / 32(94 \%)^{\mathrm{a}}$ & $31 / 32(97 \%)^{\mathrm{d}}$ & $0 / 32(0 \%)^{\mathrm{i}}$ \\
\hline
\end{tabular}

${ }^{\mathrm{a} \sim \mathrm{i}}$ Different superscripts indicate significant differences within the same column $(\mathrm{P}<0.05)$.

"PA: Embryos produced by parthenogenetic activation.

*Tables in each column represent the number of developed embryos per the number of cleaved embryos. Values in parentheses indicate percentages.

Table 3. Initiation of DNA synthesis in SCNT embryos reconstructed from G0 or G1 cells

\begin{tabular}{ccccr}
\hline & \multicolumn{4}{c}{ Duration $(\mathrm{h})$ and incorporation $(\%)$ of BrdU after nuclear transfer } \\
\cline { 2 - 5 } Groups & \multicolumn{1}{c}{$3-6 \mathrm{~h}$} & $6-9 \mathrm{~h}$ & $9-10.5 \mathrm{~h}$ & \multicolumn{1}{c}{$10.5-12 \mathrm{~h}$} \\
\hline G0-SCNT & $1 / 11(9 \%)$ & $2 / 10(20 \%)^{\mathrm{b}}$ & $17 / 27(63 \%)^{\mathrm{d}}$ & $14 / 15(93 \%)$ \\
G1-SCNT & $1 / 16(6 \%)$ & $4 / 18(22 \%)^{\mathrm{b}}$ & $24 / 28(86 \%)^{\mathrm{c}}$ & $7 / 7(100 \%)$ \\
PA & $0 / 16(0 \%)$ & $15 / 18(83 \%)^{\mathrm{a}}$ & $17 / 17(100 \%)^{\mathrm{c}}$ & $10 / 10(100 \%)$ \\
\hline
\end{tabular}

${ }^{\mathrm{a} \sim \mathrm{d}}$ Different superscripts indicate significant differences within the same column $(\mathrm{P}<0.05)$.

\#Tables in each column represent the no. of BrdU positive embryos per the no. of embryos examined.

Oct4 gene in the SCNT embryos compared with the PA embryos (Fig. 3). However, no significant differences were observed between the G0-SCNT and G1-SCNT embryos.

\section{Discussion}

Several reports refer to differences in the developmental ability of SCNT embryos 
Table 4. Developmental rates of G0-SCNT embryos treated with aphidicolin during 7-14 h after nuclear transfer

\begin{tabular}{lccccc}
\hline Groups & Treatment & $\begin{array}{c}\text { No. of } \\
\text { trials }\end{array}$ & $\begin{array}{c}\text { No. of embryos } \\
\text { examined }\end{array}$ & $\begin{array}{c}\text { No. of embryos } \\
\text { cleaved (mean } \pm \text { SD } \%)\end{array}$ & $\begin{array}{c}\text { No. of embryos to } \\
\text { blastocysts (mean } \pm \text { SD } \%)\end{array}$ \\
\hline G0-SCNT & Aphidicolin & 6 & 84 & $54(64 \pm 12 \%)$ & $4(3 \pm 4 \%)$ \\
& Control & 6 & 81 & $55(67 \pm 16 \%)$ & $26(31 \pm 17 \%)^{\mathrm{a}}$ \\
G1-SCNT & Aphidicolin & 5 & 66 & $34(53 \pm 13 \%)$ & $2(3 \pm 4 \%)$ \\
& Control & 5 & 66 & $39(58 \pm 6 \%)$ & $20(31 \pm 8 \%)^{\mathrm{b}}$ \\
\hline
\end{tabular}

${ }^{a, b}$ Values differ significantly within the same column of the same donor cell cycle stage $(\mathrm{P}<0.05)$.

Table 5. Cell numbers and proportions of ICM cells in SCNT and PA blastocysts

\begin{tabular}{cccccc}
\hline Groups & $\begin{array}{c}\text { No. of embryos } \\
\text { examined }\end{array}$ & $\begin{array}{c}\text { Total cell number } \\
(\text { mean } \pm \text { SE) }\end{array}$ & $\begin{array}{c}\text { ICM cell number } \\
(\text { mean } \pm \text { SE) }\end{array}$ & $\begin{array}{c}\text { TE cell number } \\
(\text { mean } \pm \text { SE })\end{array}$ & $\begin{array}{c}\text { ICM/TE } \\
(\text { mean } \pm \text { SE\% })\end{array}$ \\
\hline G0-SCNT & 9 & $44.2 \pm 2.0$ & $13.7 \pm 0.8$ & $30.6 \pm 1.6$ & $31.0 \pm 1.6$ \\
G1-SCNT & 11 & $43.4 \pm 2.0$ & $13.5 \pm 1.2$ & $29.8 \pm 1.5$ & $31.0 \pm 2.2$ \\
PA* $^{*}$ & 8 & $48.5 \pm 2.2$ & $13.5 \pm 0.9$ & $34.8 \pm 2.3$ & $28.2 \pm 2.2$ \\
\hline
\end{tabular}

*PA: Embryos produced by parthenogenetic activation.

A

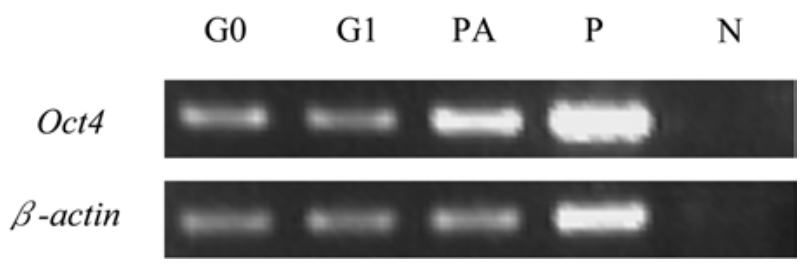

B

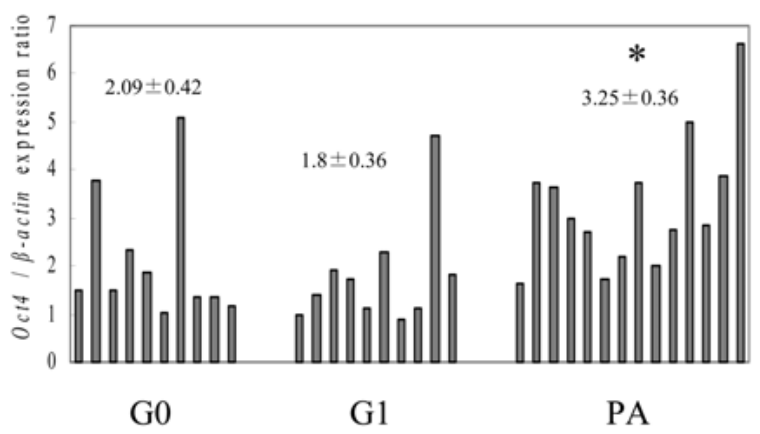

Fig. 3. Comparison of the expression of Oct4 transcripts in SCNT and PA embryos. (A) Gel electrophoresis of a semiquantitative RT-PCR product from a single G0SCNT (G0), G1-SCNT (G1) and PA embryo. P represents the positive control (Oct4 in oocytes and $\beta$ actin in fibroblasts) and $\mathrm{N}$ represents the negative control (Oct4 in fibroblasts and $\beta$-actin with no template DNA added). (B) Relative amount of Oct4 transcripts to $\beta$-actin transcripts in each blastocyst. *Value differs significantly from the other groups $(\mathrm{P}<0.05)$. reconstructed from G0 or G1 cells. Wells et al. [28] showed that for non-transgenic fibroblasts, synchronization in the G0 phase results in a higher percentage of viable calves to term than synchronization in the G1 phase, suggesting that G0 cells are superior to G1 cells as donor cells in cattle [10]. In contrast, G1 cells support a higher developmental rate to term than G0 cells in cattle [15] and exhibit higher developmental rates to term in cattle [20]. In this study, the G1-SCNT embryos had a significantly higher developmental rate to the blastocyst stage per cleaved embryo than the G0SCNT embryos (59\% for G1 and $43 \%$ for G0; $\mathrm{P}<0.05)$. This indicates that $\mathrm{G} 1$-synchronized cells can support preimplantation development of SCNT embryos and may be more effectively reprogrammed than G0 cells in porcine SCNT. Disadvantages of G0 cells may be explained by their heterogeneous cell population. G0synchronized cells obtained using the confluent cell culture system contain cells of other cell cycles or apoptotic cells $[13,14]$. Contamination of these cells may cause a lower developmental rate.

The timing of first cleavage of embryos correlates with subsequent development in some species [2933]. Duration of the 2-cell stage increased as the time before cleavage to the 2-cell stage increased in porcine embryos [29]. Early onset of first cleavage of embryos is associated with increased blastocyst formation in bovine [31] and human embryos [33] and is also related to a high pregnancy rate in 
humans [30, 32]. In the present study, G1-SCNT embryos with high developmental rates cleaved faster $24 \mathrm{~h}$ after nuclear transfer and reached the blastocyst stage earlier than the G0-SCNT embryos (Fig. 2). This suggests that the difference in donor cell cycle affects developmental progression of SCNT embryos and that earlier development of SCNT embryos may correlate with higher developmental potential. Interestingly, a considerable number of the G0-SCNT embryos (16/ $45=36 \%$ ) remained at the 2-cell stage even at the end of culture, while only $16 \%$ of the G1-SCNT embryos and $0 \%$ of PA embryos were at the 2-cell stage (Table 2). Failure of embryonic development in vitro, caused by insufficient culture conditions or a deficient developmental program, may result in developmental arrest at around embryonic genome activation [34]. Since embryonic genome activation occurs at the 4-cell stage in domestic pigs [35], developmental arrest at the 2-cell stage in this experiment was a unique phenomenon in SCNT embryos and may have been caused by the failure of nuclear reprogramming.

The timing of onset of DNA synthesis in the SCNT embryos varied and was dependent on the donor cell cycle (Table 3). When G0 cells were used as donor cells, the onset of DNA synthesis was delayed compared with that of G1 cells. Kurosaka et al. [24] also reported that donor cells at the G1/S phase initiate DNA synthesis earlier than G0-phase cells, which is in agreement with our results. This may result from the characteristics of G0 cells. Because G0 cells exit the normal cell division cycle and enter a quiescent state, much more time may be required to enter the $S$ phase. In vitro fertilized bovine embryos, which have high developmental ability to the blastocyst stage, initiate DNA synthesis earlier $[22,23]$ and have a longer $S$ phase than embryos with low developmental ability [23]. In this study, the G1-SCNT embryos entered into the $S$ phase earlier, and this resulted in a higher developmental rate. Moreover, delay of initiation of the first $S$ phase dramatically reduced the developmental rates to the blastocyst stage in the SCNT and PA embryos in this experiment. These results suggest that earlier initiation of DNA synthesis may be one of the indicators of developmental competence for SCNT embryos. The fact that a higher proportion of the G1-SCNT embryos cleaved and developed into blastocysts may be because they entered the S-phase earlier than the G0-SCNT embryos. An essential process for nuclear reprogramming and/or development of SCNT embryos may exist during the phase between first DNA synthesis and nuclear transfer into oocytes.

The effect of the cell cycle of donor cells on the morphological and biochemical aspects of SCNT embryos was examined at the blastocyst stage. The total cell numbers and the ratios of ICM cell numbers to total cell numbers in the SCNT embryos did not differ significantly between the SCNT and PA embryos (Table 5). The cell numbers and ratios of ICM cells were similar to those of in vivo porcine embryos [26], suggesting that obvious defects in cell morphology were not observed in the SCNT embryos reconstructed from G0 or G1 cells. Gene expression of undifferentiated stem cell marker Oct4 was examined at the blastocyst stage by semiquantitative RT-PCR analysis. Oct4 is a gene that encodes for a transcriptional factor required for early embryonic development [36]. The Oct4 gene is not expressed in differentiated somatic cells, and abnormal distribution of Oct4 mRNA and low levels of Oct4 expression in mouse SCNT embryos have been reported [37]. In the present study, down-regulation of Oct4 gene expression was observed in the SCNT embryos compared with the PA embryos. PA embryos obtained by the same method can be efficiently implanted until day 29 of pregnancy [38]. Taking this high implantation rate, high developmental rate to the blastocyst stage, and normal cell numbers at the blastocyst stage into consideration, the PA embryos in our experiment may have properties that are close to normal embryos, at least during preimplantaion development. Therefore, the Oct4 gene in porcine SCNT embryos may be incompletely reactivated as in mouse SCNT embryos [37]. No significant difference, however, was observed in gene expression between the G0-SCNT and G1-SCNT embryos. In porcine blastocysts, Oct 4 protein is detected in both the ICM and trophectoderm [39]. This is in contrast to the mouse [39], in which Oct4 is only expressed in ICM cells. Further investigation is needed to characterize the expression of Oct4 in porcine SCNT embryos.

The differences between the developmental patterns of the SCNT embryos from the two different donors and the PA embryos became apparent during the first cell cycle (Fig. 2 and Table 3). Many events that are associated with nuclear 
reprogramming in SCNT embryos, including replacement of somatic linker histones with oocytespecific linker histone H1FOO [40, 41], changes in the composition of nuclear lamins and nucleolar changes $[42,43]$ and formation of premature chromosome condensation [44], occur at a very early developmental stage or at least before first cleavage. Failure of these events to occur may result in abnormal loss of DNA synthesis or embryo cleavage. More studies are needed to clarify the early reprogramming events of SCNT embryos. The present experiment provides a model system for reprogramming analysis of SCNT embryos using synchronized G1 donor cells with high cellular viability and a homogeneous cell state.

\section{References}

1. Wilmut I, Schnieke AE, McWhir J, Kind AJ, Campbell KH. Viable offspring derived from fetal and adult mammalian cells. Nature 1997; 385: 810813.

2. Wakayama T, Perry AC, Zuccotti M, Johnson KR, Yanagimachi R. Full-term development of mice from enucleated oocytes injected with cumulus cell nuclei. Nature 1998; 394: 369-374.

3. Cibelli JB, Stice SL, Golueke PJ, Kane JJ, Jerry J, Blackwell C, Ponce de Leon FA, Robl JM. Cloned transgenic calves produced from nonquiescent fetal fibroblasts. Science 1998; 280: 1256-1258.

4. Baguisi A, Behboodi E, Melican DT, Pollock JS, Destrempes MM, Cammuso C, Williams JL, Nims SD, Porter CA, Midura P, Palacios MJ, Ayres SL, Denniston RS, Hayes ML, Ziomek CA, Meade HM, Godke RA, Gavin WG, Overstrom EW, Echelard Y. Production of goats by somatic cell nuclear transfer. Nat Biotechnol 1999; 17: 456-461.

5. Onishi A, Iwamoto M, Akita T, Mikawa S, Takeda K, Awata T, Hanada H, Perry AC. Pig cloning by microinjection of fetal fibroblast nuclei. Science 2000; 289: 1188-1190.

6. Shin T, Kraemer D, Pryor J, Liu L, Rugila J, Howe L, Buck S, Murphy K, Lyons L, Westhusin M. A cat cloned by nuclear transplantation. Nature 2002; 415: 859.

7. Chesne P, Adenot PG, Viglietta C, Baratte M, Boulanger L, Renard JP. Cloned rabbits produced by nuclear transfer from adult somatic cells. Nat Biotechnol 2002; 20: 366-369.

8. Galli C, Lagutina I, Crotti G, Colleoni S, Turini P, Ponderato N, Duchi R, Lazzari G. Pregnancy: a cloned horse born to its dam twin. Nature 2003; 424: 635.

9. Zhou Q, Renard JP, LeFriec G, Brochard V, Beaujean N, Cherifi Y, Fraichard A, Cozzi J. Generation of fertile cloned rats by regulating oocyte activation. Science 2003; 302: 1179.

10. Oback B, Wells D. Donor cells for nuclear cloning: many are called, but few are chosen. Cloning Stem Cells 2002; 4: 147-168.

11. Oback B, Wells D. Practical aspects of donor cell selection for nuclear cloning. Cloning Stem Cells 2002; 4: 169-174.

12. Kues WA, Anger M, Carnwath JW, Paul D, Motlik J, Niemann H. Cell cycle synchronization of porcine fetal fibroblasts: effects of serum deprivation and reversible cell cycle inhibitors. Biol Reprod 2000; 62: 412-419.

13. Kues WA, Carnwath JW, Paul D, Niemann H. Cell cycle synchronization of porcine fetal fibroblasts by serum deprivation initiates a nonconventional form of apoptosis. Cloning Stem Cells 2002; 4: 231-243.

14. Boquest AC, Day BN, Prather RS. Flow cytometric cell cycle analysis of cultured porcine fetal fibroblast cells. Biol Reprod 1999; 60: 1013-1019.

15. Kasinathan P, Knott JG, Wang Z, Jerry DJ, Robl JM. Production of calves from G1 fibroblasts. Nat Biotechnol 2001; 19: 1176-1178.

16. Hayes O, Ramos B, Rodríguez LL, Aguilar A, Badía T, Castro FO. Cell confluency is as efficient as serum starvation for inducing arrest in the G0/G1 phase of the cell cycle in granulosa and fibroblast cells of cattle. Ani Reprod Sci 2005; 87: 181-192.

17. Kubota C, Yamakuchi H, Todoroki J, Mizoshita K, Tabara N, Barber M, Yang X. Six cloned calves produced from adult fibroblast cells after long-term culture. Proc Nat Acad Sci USA 2000; 97: 990-995.

18. Wakayama T, Rodriguez I, Perry AC, Yanagimachi R, Mombaerts P. Mice cloned from embryonic stem cells. Proc Nat Acad Sci USA 1999; 96: 14984-14989.

19. Ono Y, Shimozawa N, Ito M, Kono T. Cloned mice from fetal fibroblast cells arrested at metaphase by a serial nuclear transfer. Biol Reprod 2001; 64: 44-50.

20. Urakawa M, Ideta A, Sawada T, Aoyagi Y. Examination of a modified cell cycle synchronization method and bovine nuclear transfer using synchronized early G1 phase fibroblast cells. Theriogenology 2004; 62: 714-728.

21. Schabronath J, Gartner K. Paternal influence on timing of pronuclear DNA synthesis in naturally ovulated and fertilized mouse eggs. Biol Reprod 1988; 38: 744-749.

22. Eid LN, Lorton SP, Parrish JJ. Paternal influence on S-phase in the first cell cycle of the bovine embryo. 
Biol Reprod 1994; 51: 1232-1237.

23. Comizzoli P, Marquant-Le GB, Heyman Y, Renard JP. Onset of the first S-phase is determined by a paternal effect during the G1-phase in bovine zygotes. Biol Reprod 2000; 62: 1677-1684.

24. Kurosaka S, Nagao Y, Minami N, Yamada M, Imai H. Dependence of DNA synthesis and in vitro development of bovine nuclear transfer embryos on the stage of the cell cycle of donor cells and recipient cytoplasts. Biol Reprod 2002; 67: 643-647.

25. Hoshino $\mathbf{Y}$, Uchida $M$, Shimatsu $\mathbf{Y}$, Miyake $M$, Nagao $Y$, Minami $N$, Yamada $M$, Imai $H$. Developmental competence of somatic cell nuclear transfer embryos reconstructed from oocytes matured in vitro with follicle shells in miniature pig. Cloning Stem Cells 2005; 7: 17-26.

26. Yoshioka K, Suzuki C, Tanaka A, Anas IM, Iwamura S. Birth of piglets derived from porcine zygotes cultured in a chemically defined medium. Biol Reprod 2002; 66: 112-119.

27. Wright GE, Hubscher U, Khan NN, Focher F, Verri A. Inhibitor analysis of calf thymus DNA polymerases alpha, delta and epsilon. FEBS Lett 1994; 341: 128-130.

28. Wells DN, Laible G, Tucker FC, Miller AL, Oliver JE, Xiang T, Forsyth JT, Berg MC, Cockrem K, L'Huillier PJ, Tervit HR, Oback B. Coordination between donor cell type and cell cycle stage improves nuclear cloning efficiency in cattle. Theriogenology 2003; 59: 45-59.

29. Prather RS, Hoffman KE, Schoenbeck RA, Stumpf TT, Li J. Characterization of DNA synthesis during the 2-cell stage and the production of tetraploid chimeric pig embryos. Mol Reprod Dev 1996; 45: 38 42.

30. Shoukir Y, Campana A, Farley T, Sakkas D. Early cleavage of in-vitro fertilized human embryos to the 2-cell stage: a novel indicator of embryo quality and viability. Hum Reprod 1997; 12: 1531-1536.

31. Lonergan $\mathbf{P}$, Khatir H, Piumi F, Rieger D, Humblot P, Boland MP. Effect of time interval from insemination to first cleavage on the developmental characteristics, sex ratio and pregnancy rate after transfer of bovine embryos. J Reprod Fertil 1999; 117: 159-167.

32. Bos-Mikich A, Mattos AL, Ferrari AN. Early cleavage of human embryos: an effective method for predicting successful IVF/ICSI outcome. Hum Reprod 2001; 16: 2658-2661.

33. Fenwick J, Platteau P, Murdoch AP, Herbert M.
Time from insemination to first cleavage predicts developmental competence of human preimplantation embryos in vitro. Hum Reprod 2002; 17: 407-412.

34. Abeydeera LR. In vitro production of embryos in swine. Theriogenology 2002; 57: 256-273.

35. Maddox-Hyttel P, Dinnyes A, Laurincik J, Rath D, Niemann H, Rosenkranz C, Wilmut I. Gene expression during pre- and peri-implantation embryonic development in pigs. Reprod Suppl 2001; 58: 175-189.

36. Rosner MH, Vigano MA, Ozato K, Timmons PM, Poirier F, Rigby PW, Staudt LM. A POU-domain transcription factor in early stem cells and germ cells of the mammalian embryo. Nature 1990; 345: 686692.

37. Boiani M, Eckardt S, Scholer HR, McLaughlin KJ. Oct4 distribution and level in mouse clones: consequences for pluripotency. Genes Dev 2002; 16: 1209-1219.

38. Kure-bayashi S, Miyake M, Okada K, Kato S. Successful implantation of in vitro-matured, electroactivated oocytes in the pig. Theriogenology 2000; 53: 1105-1119.

39. Kirchhof N, Carnwath JW, Lemme E, Anastassiadis $\mathrm{K}$, Scholer $\mathrm{H}$, Niemann $\mathrm{H}$. Expression pattern of Oct-4 in preimplantation embryos of different species. Biol Reprod 2000; 63: 1698-1705.

40. Gao S, Chung YG, Parseghian MH, King GJ, Adashi EY, Latham KE. Rapid H1 linker histone transitions following fertilization or somatic cell nuclear transfer: evidence for a uniform developmental program in mice. Dev Biol 2004; 266: 62-75.

41. Teranishi T, Tanaka $\mathbf{M}$, Kimoto S, Ono $\mathbf{Y}$, Miyakoshi K, Kono T, Yoshimura Y. Rapid replacement of somatic linker histones with the oocyte-specific linker histone H1foo in nuclear transfer. Dev Biol 2004; 266: 76-86.

42. Moreira PN, Robl JM, Collas P. Architectural defects in pronuclei of mouse nuclear transplant embryos. J Cell Sci 2003; 116: 3713-3720.

43. Prather RS, Sutovsky P, Green JA. Nuclear remodeling and reprogramming in transgenic pig production. Exp Biol Med 2004; 229: 1120-1126.

44. Campbell KH, Alberio R, Lee JH, Ritchie WA. Nuclear transfer in practice. Cloning Stem Cells 2001; 3: 201-208. 